\title{
'Accounting for Privatisation in Bangladesh: Testing World Bank Claims
}

Article in Critical Perspectives on Accounting • October 2003

DOI: 10.1016/S1045-2354(02)00188-0

2 authors: 


\title{
ACCOUNTING FOR PRIVATISATION IN BANGLADESH: TESTING WORLD BANK CLAIMS*
}

\author{
Shahzad Uddin** \\ Department of Accounting, Finance and Management \\ University of Essex \\ Wivenhoe Park \\ Colchester \\ C04 $3 S Q$ \\ $U K$ \\ and \\ Trevor Hopper \\ Manchester School of Accounting and Finance \\ University of Manchester \\ Manchester, M13 9PL \\ UK
}

We wish to thank the Commonwealth Awards scheme and the CIMA Research Foundation for helping fund this research.

** Corresponding author. Tel. 01206872546

Email addresses: shahzad100@hotmail.com (S.Uddin), trevor.hopper@man.ac.uk (T.Hopper) 


\section{ACCOUNTING FOR PRIVATISATION IN BANGLADESH: TESTING WORLD BANK CLAIMS}




\title{
ACCOUNTING FOR PRIVATISATION IN BANGLADESH: TESTING WORLD BANK CLAIMS
}

\begin{abstract}
The World Bank and the IMF have encouraged many less developed countries (LDCs) to pursue privatisation policies. Development economists and World Bank reports claim this facilitates development by improving controls within enterprises and external regulation of financial markets acting on external accounting reports. This paper questions these beliefs. It compares the postprivatisation performance of companies in Bangladesh examined in a World Bank report with the authors' own research on the same companies. The World Bank report reported that the success of the privatisations established the case for more. In the research reported here, only one of the privatised companies was judged a commercial success, though the unavailability and dubious accuracy of accounting reports prevented any definitive assessment. Above all, the paper questions the narrow criteria adopted by the World Bank report - namely profitability - and the neglect of employment conditions, trade union and individual rights; social returns; and financial transparency and accountability to external constituents. Our evidence suggested that privatisation has not increased returns to society: privatised companies' contributions to state revenue declined in real terms and as a proportion of value added. Transparent external reports failed to materialise as required by law and there was evidence of untoward transactions affecting minority shareholders, creditors, and tax collecting institutions. Internal controls may have become more commercial but at the cost of declining employment, wages, quality of working life, and employee rights. The World Bank claims rest upon efficiency benefits trickling down to all but the effects of privatisation may have been a redistribution of power and wealth to the new owners. This paper argues that the IMF, the World Bank, and Western capitalist states have not provided the technical infrastructure and organisational capacity to execute their neo-liberal privatisation agenda, which rests on dubious socio-economic assumptions. Our unfavourable evaluation of privatisation in Bangladesh is not unique. It has been happening again and again around the World.
\end{abstract}

Key words: World Bank, Privatisation, Accounting, Performance, Accountability, Bangladesh 


\section{INTRODUCTION}

The World Bank and the IMF have encouraged many less developed countries (LDCs) to pursue privatisation policies (Cook, 1986; Cook and Kirkpatrick, 1995; Craig, 2000). It is difficult for many LDCs to resist (Cook, 1986, p.24). To do otherwise might debar them from crucial concessionary finance from the World Bank, IMF, and northern aid donors (Craig, 2000). Some governments of LDCs have adopted privatisation programmes of their own volition but others have grudgingly done so under pressure from governments of industrialised countries acting through international agencies. Privatisation is usually a component of structural adjustment programmes based on notions of economic liberalisation, free trade, competition, privatisation, and limited government intervention (Cook, 1986, p.18). The argument is that better resource allocation will emerge from institutional reforms including: greater market pricing; removing restrictions or quotas for imports; promoting the private sector; curtailing government activities through divesture or closure of state enterprises; and contracting out government functions to the private sector (Toye, 1994). The premise is that private, rather than public ownership, produces more efficient enterprises with benefits for consumers, employers, industry, and the nation (Adam et al., 1992; Hanke, 1986; Rees, 1984; Furubotn and Pejovich, 1972; Donald and Hutton, 1998, p. 460; Flemming and Mayer, 1997, p. 4; Goodman and Loveman, 1991, p. 26; Ogden, 1995, p. 146, 1997, pp. 529-530; Shaoul, 1997). Crucially (but too often neglected) privatisation policies presume the improved accounting that underpins their prescriptions will materialise.

This paper questions these beliefs. Its comparison of the post-privatisation performance of Bangladesh companies examined in a World Bank report ${ }^{1}$ with the authors' research on the same companies raises issues about the accuracy of the World Bank report, its policy prescriptions, and its criteria of effectiveness. World Bank claims that privatisation brings more transparent accounting and improved economic performance appear dubious, along with presumptions that it facilitates development goals such as increased investment, GDP, productivity and employment. 
The paper initially describes the events in Bangladesh leading up to privatisation policies. Then it examines the arguments for structural adjustment programmes - especially privatisation, how donor agencies help devise such programmes, and how they are underpinned by assumptions of accounting changes. After briefly delineating the research methods, the paper compares and contrasts the researchers' findings with those in the World Bank report. The first part examines changes in accounting practices and economic performance revealed in an intensive case study of a soap firm (hereafter anonymised as PC). The second part examines the same issues in the other privatised firms in the World Bank report. The paper concludes by reflecting on why the two sets of research diverge, and policy implications, not least regarding accounting.

\section{PRIVATISATION IN BANGLADESH}

The Bangladeshi government embarked upon privatisation programmes and public sector reforms following pressure from the World Bank and IMF (Cook and Kirkpatrick, 1995; Hemming and Mansoor, 1988; Cook, 1986). Although the policies may mimic reforms in developed economies (Hood, 1991), this needs to be understood in the context of Bangladesh's brief history (see Uddin and Hopper, 1999, 2001). After liberation in 1971, Bangladesh inherited an economy dominated by the private sector. The new government, led by Sheikh Mujibur Rahman, was committed to socialism and nationalising heavy industries. It also faced an industrial ownership vacuum as fleeing West Pakistanis abandoned their industrial and commercial companies. The government included all abandoned property within programmes of state ownership of industry, agricultural self-sufficiency, import substitution, and industrialisation based on state intervention and central planning (Government of Bangladesh, 1972). By 1974, the public sector controlled about 350 state owned companies (SOEs) responsible for over $92 \%$ of total fixed assets of the industrial sector. However, their inefficiency adversely affected public investment (Ghafur, 1976; Ahmad, 1976a; World Bank, 1993): their losses consumed 30\% of annual project aid. 
Not surprisingly, this strengthened the hand of adversaries of the public sector. A military coup overthrew the Sheikh Mujib Government and Mujib was assassinated in August 1975. Three months later, through another coup, General Ziaur Rahman came to power, assuming full control in 1977. His government initiated liberal economic policies leading to some small (Bengali-owned) companies being returned to their owners. A disinvestment board was established resulting in 255 SOEs, including "abandoned" and vested properties, being divested or privatised between 1975 and 1981 (World Bank, 1997).

International lending agencies became a major influence upon government policies. The World Bank emerged as the Praetorian Guard of the Donor Countries Consortium (DCC). It assumed formal responsibility for reporting on the state of the nation to DCC members, and used the DCC's collective sanctions to enforce Bank directives requiring the government to promote the private sector and markets. The Bank's enhanced authority emerged from the economic dependence and political weakness of Bangladesh (Sobhan, 1982), nevertheless internal politics played a role (Adam et al., 1992; Hemming and Mansoor, 1988; Cook, 1986; Ramanadhan, 1989). Military leaders in Bangladesh turned to Western ideologies, especially Thatcherism and Reaganism, to legitimise their undemocratic actions.

In 1982, General Ershad overthrew the Bangladesh Nationalist Party (BNP) Government. The vulnerable Ershad Government solicited Western support by adopting their recommendations to privatise SOEs. As donor agencies tended to make loan facilities conditional upon privatisation (whether SOEs were loss making or not), the government had little choice. 27 textile mills and 33 jute mills were returned to their original Bangladeshi owners within a year. Nevertheless, until 1986, the scope of privatisation was limited. The quantity of privatisations was large but they were mainly small factories and mills, for example they provided less than $\mathrm{TK}^{2} .2$ billion to government receipts. They were easy to privatise, being economically and politically insignificant, whereas most SOEs were unionised, had strong links to political parties, and labour militancy could overthrow governments. 
In 1986 industrial policy further reduced the role of the state. Many SOEs became joint stock companies in a holding company (Board of Investments) responsible for selling subsidiary companies' shares under the '51-49 Plan'. ${ }^{3}$ In 1991, a re-elected BNP government, advised and financed by the World Bank, paved the way for more privatisation by liberalising foreign trade, relaxing exchange controls, and restructuring import tariffs. In 1991, to assist this, the Asian Development Bank (a sister organisation of the World Bank) financed a public sector redundancy programme called "Improvement of Labour Productivity in the Public Sector Enterprises" (the "Golden Handshake Programme'). 1264 workers were laid off in selected SOEs to reduce worker resistance to privatisation. However, the Asian Development Bank withdrew the 'Golden Handshake' project because the Government of Bangladesh failed to recompense redundant workers within the strict time limit. This meant the Bangladesh government could not pay redundant workers: labour retrenchment slowed, and production suffered due to trade union disputes. In 1993, the government established the Privatisation Board following World Bank pressure for a speedier and more independent privatisation process. However, from 1991 to 1996, the Board only privatised 13 of the 40 SOEs targeted in the Aid Group meeting of October 1991 (these companies are the focus of this paper). Nevertheless, the incoming 1996 Awami League government maintained a commitment to privatisation [The Daily Star (Bangladesh), 14 June, 1996] and promised donor agencies they would intensify such programmes (The Bangladesh Observer, 1 January, 1997). World Bank reports (1993, 1995, 1996, 1996a, 1996b) had shaped political opinion that Bangladesh SOEs were inefficient but from 1996 to 2001 only 9 small SOEs were fully privatised. Again, this fell short of expectations.

Policy makers in Bangladesh, influenced by economic advisors of a neo-classical hue, claimed privatisation will improve the governmental fiscal situation, the efficiency of companies, and financial signalling, and hence promote investment and growth in the medium-term to levels impossible under public ownership (p. 2, World Bank, 1995). Opponents pointed out that Bangladesh SOEs pursue a wide range of development objectives: maximising profits was only ranked fifth by managers, below contributions to national development and providing employment (ADB survey in World Bank, 1995). 
The World Bank (1995) responded that no company could be competitive unless it pursued profit maximisation, and that private firms in Bangladesh had greater productivity and profitability than SOEs.

Studies of the post-privatisation performance of Bangladesh firms are few. Sobhan and Ahsan (1984) found that denationalised jute mills performed no better than public sector mills. In some cases, the production of denationalised mills fell by a larger percentage than their public sector counterparts, whose profit per ton was often higher. They concluded that privatised mills did not improve their financial performance (p.187-188, Ahmad, 1994). Humphrey (1990), commissioned by USAID, concluded: "Privatization in Bangladesh has been a mixed bag ... it is difficult to trace, much less gauge, the post-privatization performance of many divested firms. A native unwillingness to share financial information - whether showing profit or loss - combines with the generally unsettled and unstable condition of the Bangladesh economy to thwart the investigator" (ibid, p.160). He added: "In Bangladesh's jumbled, backward economy, there are powerful adverse forces and factors with greater influence in determining an enterprise's fate than its own performance. Some of these forces and factors arise from the nature of the marketplace in Bangladesh; some stem from the policies, programs, and procedures of the government" (ibid, p.161).

Lorch (1990, reported in World Bank, 1995) and Sobhan (1991) conducted cross-sectional comparisons of Bangladesh privatised enterprises and SOEs reaching inconclusive results. Sobhan (1991) after examining divested small, medium and large units noted that:

The BOI (Board of Investments) has 497 disinvested enterprises registered with it. Of these units, the BOI managed early in 1991 to survey for the first time 290 or 58 per cent of the registered units. Of these surveyed units, only 137 or 47 per cent were found to be in operation. 75 or 26 per cent of the units had ceased production. Another 78 or 27 per cent of the disinvested units had been abandoned altogether and were using the premises for other purposes ... the impression ... was that of the 137 units in operation, many were not in good shape (ibid, p.148). 
A World Bank reported (1993) that privatised jute and textile mills failed after privatisation: some were liquidated, whilst others made losses. Private investment did not increase as much as expected following privatisation, fluctuating between 5.5\% G.D.P. to $6.5 \%$ G.D.P.

Ahmad's study (1993), similar to a World Bank report (1993), found no significant evidence of greater efficiency in privatised jute and cotton textile mills. Ahmad (1994) commented on the distributional impact of privatisation in Bangladesh, claiming it had created insecurity among the labouring class that could lead to social instability, partly because privatised units refused to implement awards by the wages commission and have withdrawn fringe benefits and social expenditures common in SOEs. Thus privatization has resulted in distributional disadvantages for employees (p. 192, Ahmad, 1994). More recently, the Minister of Industries commented that:

... We must remember that all this privatisation did not bring us desired benefits. Out of 520 privatised industries 60 per cent of those closed down in the absence of proper framework of operation (published in "The Independent", Dhaka, 25 th March, 2002)

Criticisms of privatisation include the failure to repay debts incurred from privatisation, allegations of collusion and corruption during tendering, the apparent lack of post-privatisation profitability, closure of companies, and failures to meet employee entitlements. The World Bank report examined in this paper was commissioned to address such criticisms. It examined whether SOEs privatised by the Privatisation Board during 1991-1996 had added to the nation's economic growth, or simply vanished as critics claimed. Whatever, the post-privatisation record of former state enterprises is a major issue in Bangladeshi intellectual society (Ghafur, 1976; Ahmad, 1976; World Bank, 1997). ${ }^{4}$ 


\section{PRIVATISATION, PUBLIC SECTOR FAILURE, AND ACCOUNTING}

Privatisation policies in LDCs are a response to public sector control problems. A common research finding is that accounting controls become irrelevant in state owned enterprises (SOEs) because political influence over decisions outweigh commercial considerations and bypass formal accountability systems (Jones and Sefiane, 1992). For example, Ouibrahim and Scapens (1989) found the state in Algeria determined costs and prices, the completion of projects, availability of materials, and production capacity of its SOEs. Several studies of Bangladesh SOEs found bureaucratic rule-bound controls were maintained but largely ignored because decisions were politicised (Uddin and Hopper, 2001; Hoque and Hopper, 1994, 1997; Alam, 1990, 1997; Murshed, 1989; Uddin, 1987). Technically sound accounting systems operated within centralised state planning but were irrelevant for managers as they bore little semblance to operational realities. Accounting appeared to exist to legitimate state activities to external aid agencies by demonstrating the appearance, rather than the substance, of financial accountability and rational economic planning. Not surprisingly, there was widespread managerial dissatisfaction with controls, which was reflected in poor enterprise performance.

Advocates of privatisation presume that ownership changes will induce superior management controls, and hence greater productive and allocative efficiency (Vickers and Yarrow, 1988). Productive efficiency stems from micro-economic theories of property rights and agency within contractual relationships (Adam et al., 1992), whereas allocative efficiency emphasises the macro-economic benefits of private ownership and markets upon public finances and capital investments (Cook and Kirkpatrick, 1995). According to neo-classical economic theory, productive and allocative efficiency gains are unlikely in SOEs because political interference leads to poorly motivated, badly paid and inadequately monitored managers. In addition, the economic dominance of SOEs and their powerful labour unions combine to reduce the productive efficiency of SOEs by securing unwarranted concessions from the state (Hemming and Mansoor, 1988). 
Property right theory expounds that managers minimise costs if their rewards are directly related to economic performance (Furubotn and Pejovich, 1972). It is argued that in SOEs no one has an incentive to improve economic performance: perceived costs will outweigh benefits since the latter do not accrue to individuals (Hanke, 1986). It is alleged that performance-related pay systems are difficult to operate in SOEs (Rees, 1985): principal-agent relationships in the private sector are simpler as goals are less diffuse, and shareholders have information from published accounts to monitor management and sanction them accordingly (Adam et al, 1992). In an efficient capital market, companies that fail to meet potential have low share values, rendering them vulnerable to hostile take-overs and/or the removal of recalcitrant managers. Such threats create self-regulating incentives that are absent in SOEs (Jensen and Meckling, 1976).

World Bank reports $(1995,1996)$ justifying privatisation emphasise the lack of financial accountability and transparency in SOEs, and their immunity from market disciplines and the scrutiny of legal institutions. World Bank reports $(1993,1995,1997)$ and the IMF emphasise the importance of creating an "Enabling Environment" in Bangladesh to promote accountability, transparency and efficiency in companies. This includes: liberalising domestic and foreign trade, relaxing price controls, balanced government budgets; and a legal framework and systems of financial reporting and accountability conducive to the functioning of a market economy.

Most research on internal accounting controls and privatisation is on developed countries (Jones, 1985, 1992; Espeland and Hirsch, 1990; Wright et al., 1993; Ogden, 1993). Espeland and Hirsch (1990) claim that accounting controls helped legitimate ownership changes. Wright et al. (1993) found that a privatisation through management buy-out produced better financial control systems, employment contracts and negotiating machinery, and the release of investment constraints on subsidiaries. Letza and Smallman (2001) argue that the Yorkshire Water privatisation failed because it was too focused on aligning directors' and shareholders' interests and ignored the public good. Ogden $(1993,1994)$, the most comprehensive accounting study of privatisation and control, demonstrates how accounting 
controls created customers and markets for privatised UK Water companies and transformed political objectives into apparently organisational performance matters. Wickramasinghe (1996), one of the few accounting studies on accounting controls and privatisation outside developed countries, concluded that economic theories were insufficient for explaining changes in accounting controls in a Sri Lankan textile mill after privatisation given the importance of traditional cultural expectations and obligations, and postcolonial politics.

Research on external accounting reports in the context of structural adjustment programmes especially in LDCs is scarce. Wallace's (1988) work on financial reporting in Nigeria is a notable exception. He found inadequate regulations for disclosure and significant evidence of non-compliance with disclosure regulations by listed companies. Non-compliance problems were compounded by structural adjustment policies adopted by the Nigerian Government under pressure from the World Bank. He argued that these policies led to short-run cost reduction strategies and made corporate managers reluctant to disclose information in accounting reports.

There is, however, relevant research on financial accounting generally in LDCs (Ahmed and Nicholls, 1994; Abu-Nassar and Rutherford, 1996; Larson, 1993; Wallace and Briston, 1993; Larson and Kenny, 1995; Perera, 1975, 1989). Larson and Kenny (1995) found no clear association between economic growth, equity market development, and LDCs adopting International Accounting Standards. Narayanaswamy (1996) found the quality of financial reporting disclosures in India remained low despite widespread regulatory reforms to internationalise and liberalise business. He argued that disclosures are not merely a function of legislation but of market forces, which are weak in LDCs such as India. Ahmed and Nicholls (1994) found significant evidence of non-compliance with Stock and Securities Exchange regulations and Company Law by Bangladeshi listed companies. Only 63 company reports were available out of a sample of 95 companies for the fiscal year 1987-88. Many companies did not hold annual general meetings on due dates, or send their reports to the Stock Exchange, and many did not publish or possibly even prepare annual reports. They argued that stronger monitoring and enforcement mechanisms would make private companies comply more with 
accounting regulations. Abu-Nassar and Rutherford (1996) found that users of annual accounting reports in Jordan doubted their reliability and credibility - users were more interested in collecting insider information by visiting firms and contacting managers. Perera (1975) found Sri Lankan companies were more interested in preparing tax returns than accounting reports. Weak capital markets and poor enforcement of accounting regulations, a culture of tax avoidance, and accounting education inappropriate to the local environment caused a lack of transparency and accountability. In summary, the weight of evidence on regulatory failures in LDCs does not auger well for the likely compliance of privatised companies.

Lastly, there are concerns over the privatisation process. Privatisation policies produce massive transfers of public wealth into private hands. As experience of privatisation deepens, analysts are beginning to measure and assess the wealth transfers that take place (Arnold and Cooper, 1999; Shaoul, 1997). For example, Ahmad (1994)'s study found the privatisation process in Bangladesh is mechanical and bureaucratic, and subject to patronage. The successful bidder makes a down payment of 10-25 per cent of the negotiated price before transfer of the enterprise. However, this is often loaned from nationalised commercial banks following political pressures. The balance owed should be paid from profits but, in a society where democratic accountability is absent, defaults are common (p. 187; see also World Bank, 1997). Concerns over the distribution effects of privatisation are not exclusive to Bangladesh. For example, Martin (1995) found an apparently "successful privatisation" of a Mexican telecommunications privatisation company - Telmex - brought foreign buyers gains of \$12-billion in share values in the first year, largely because tariffs increased but "the big losers are consumers, worse off by \$33-billion.' Catchpowle and Cooper (1999) found the South African government received nothing from selling Aventura - a holiday resort chain. A similar story may be evident in Bangladesh.

In summary, structural adjustment programmes, globalisation, and the internationalisation of accounting practices may not necessarily improve accountability and transparency of companies in LDCs. Similarly, opinions are divided on whether privatisation improves enterprise performance, facilitates development goals, distributes wealth fairly, and induces more effective controls, 
accountability and transparency in LDCs. The authors' desire to address the substance of these debates at an organisational level motivated their research.

\section{RESEARCH METHODS}

The research was conducted in three phases. The first - an intensive case study - was conducted from February to September 1995 in a firm (anonymised as PC) privatised by the Privatisation Board in 1993. Data came from interviews, participation observation, and analysis of relevant documents and newspaper reports. An author worked in the soap division for one month as a casual worker. In addition, fifty-five interviews were conducted with managers (past and present), accounting staff, foremen, and trade union leaders from PC, civil servants, and World Bank officials. The second phase was carried out during summer 1999 when the main researcher conducted a follow up study. Seven interviews were conducted with senior managers in PC and some clerical staff. Permission was not granted to talk to workers or trade union leaders due to industrial relations disturbances. The results, methods, and underlying theory from these two research phases are reported in more detail in Uddin and Hopper (2001).

The final phase took place during summer 2001 as part of a larger project on the effects of privatisation on accounting, accountability, and performance, and their implications for development policies of LDCs. The aim was to compare and contrast the researchers' evaluation of the performance of the thirteen companies privatised by the Privatisation Board during 1991 to 1996 with the conclusions of a World Bank report on the same companies (1997). The World Bank report was important as it assessed past privatisations and contributed to framing future policy. The thirteen companies are not a representative sample of privatised companies in Bangladesh: thus the results cannot provide a statistical generalisation on the effectiveness of privatisation in Bangladesh. Nevertheless, the paper is a contribution to this debate, though it is primarily concerned with evaluating the quality, orientation, and criteria of World Bank inputs into policy arenas. 
Given the problems of survey responses and the desire for a $100 \%$ response rate, the research relied on a semi-structured interview with either the senior accountant or owner-manager in each company. This focussed on performance and accountability since privatisation. In addition, annual reports of each company for the previous 20 years were collected from SOEs (i.e. reports of companies preprivatisation) and from the Dhaka Stock Exchange for the four listed companies post-privatisation. Access to the reports of private companies was more difficult but during the interviews annual reports or partial financial statements were collected from six of the remaining nine private companies. One privatised company could not be located (allegedly vanished!) and two companies refused access to their financial reports. Observations during each visit evidenced each company's current physical and economic circumstances and supplemented documentation on changes in worker rights, transparency, and accountability.

\section{A CASE STUDY OF CHANGED ACCOUNTING CONTROLS AND PERFORMANCE IN A PRIVATISED COMPANY}

\section{Public Ownership}

PC, a soap and cosmetics manufacturer was founded in 1959 by private West Pakistani owners and became profitable immediately. It rapidly expanded its markets, product range, production capacity, and profits aided by trade protection from the then Pakistan Government. PC was nationalised after independence in 1971 and its accounting came under strict, formal scrutiny at various government levels. Rigid rules and regulations governed the preparation and approval of accounts ${ }^{5}$ (Government of Bangladesh, 1976; Uddin and Hopper, 1999). PC was part of a budgeting system extending from the company, through its Head Office, to government ministries responsible for industrial development and state central planning. This resulted in a large and busy accounting department at PC.

On the face of it, PC was subject to strict, open, externally scrutinised accountability systems. However, whilst financial accounts were essentially sound technically and procedurally, they were not 
significant conduits of accountability, being rarely discussed within Parliament or its relevant committees. Similarly, the budgeting system fell into disrepute. Government and HQ officials constantly sought higher production to demonstrate their achievements and they pressured HQ managers to institute bonuses for employees based on short-run physical production targets. Thus production targets superseded the financial budget and production managers colluded with workers to manipulate results. Accounting and budgets were a ceremonial ritual, and budget behaviour became rule-bound and ritualistic. Managers made them compatible with official regulations and rules to satisfy higher officialdom but controlled operations through unofficial, informal and occasionally unethical deals with trade union leaders. It was widely recognised that decisions lay primarily with politicians acting through, and at the behest of their respective party-based trade union. The annual budget was neither regularly reviewed, nor was it integrated with physical controls. These control problems were pervasive and extended to marketing, pricing, financing, and procurement decisions. The ostensibly rational legal bureaucracy established upon nationalisation, with a modernistic belief in centrally planned development, proved inadequate in the face of politics (Sobhan and Ahmad, 1980). This is consistent with other studies in Bangladesh and other LDCs (Hoque and Hopper, 1994, 1997; Ouibrahim and Scapens, 1989; Uddin, 1987; Jones and Sefiane, 1992; Wickramsinghe, 1996).

Nevertheless, PC's productivity from 1979-80 to 1987-88 was good compared to similar enterprises in Bangladesh (Bangladesh Bureau of Statistics, 1993). Capacity utilisation ranged from $105 \%$ to $51 \%$ and averaged $70 \%$. Up to $1988-89$, PC increased sales and never incurred a loss. 1985-86 saw PC's best return on capital employed (ROCE) of $29.2 \%$ and $1987-88$ the worst of $2.3 \%$. In the last eight years of public ownership PC's ROCE averaged 12.4\%. From 1983 to 1988 PC generated 896m. TK value added. From 1982 to 1988, 78\% of value added (an annual average of TK. 139m. TK) was paid the government in taxes and duties and workers received $22 \%$ (an average of $40 \mathrm{~m}$. TK). PC was a profitable concern under state capitalism with many of the benefits flowing to government.

In 1988 the government nominated PC for partial privatisation at the behest of donor agencies including the World Bank. 49\% of shares were placed in private hands with the government retaining 
a $51 \%$ controlling interest. The public reason given for the privatisation was to rectify PC's control problems though some allege it was because PC was profitable and thus saleable, and not as politically sensitive as other larger SOEs.

Financial accounting and budget systems changed following corporatisation as PC became subject to the Company Act and, as a listed company, Stock Exchange regulations and Securities Exchange Commission rules. Accounting systems became more complex as PC had to comply simultaneously with its holding company's directives and the Company Act. Although it was often difficult to satisfy both, PC's external reporting systems met Company Act regulations requiring an auditor to be appointed by shareholders and the publication of annual accounting reports. However, auditing remained essentially a ceremonial tool as the holding company, being the major shareholder, effectively appointed the auditors. State bureaucrats and politicians retained their hold over major decisions: problems associated with bureaucracy and politicisation persisted and budgeting remained ineffective. The ownership changes brought severe organisational problems: directors nominated by government organs repeatedly clashed with directors representing private shareholders and shop floor unrest increased due to trade union agitation against privatisation.

The result was a dramatic decline in performance. By 1993 sales had declined to $247 \mathrm{~m}$. TK producing a loss of TK. $60.36 \mathrm{~m}$. Over the five years of partial privatisation PC accumulated a loss of TK. $173 \mathrm{~m}$. resulting in a negative return on capital employed. Government receipts decreased and there were marked decreases in production, for example soap production dropped from 10545 Metric Tons (MT) in $1988-89$ to 2793 MT in 1992-93. Capacity utilisation dropped from $53 \%$ in $1988-89$ to $14 \%$ in 1992-93: average capacity utilisation over the partial privatisation period was only $25 \%$. In 1988 the total workforce was 1261 (1091 manual and clerical workers and 170 officers) - by 1991 it was 1100 . 


\section{Private Ownership}

PC was fully privatised in August 1993. The state and aid agencies such as the World Bank and IMF saw full privatisation as the solution to partial privatisation's reversal of profitability. Justifying the government's decision, a government official remarked, "The Government and [the holding company] could not bear these losses because they were affecting other units of [the holding company] and the government. Therefore, we had to take the decision of selling the government's shares to the public". PC's managers had a different view. One commented, "It was an intentional move of the policymakers and directors (potential buyers) because this situation created the necessary grounds for complete privatisation." Whatever, the government sold their shares $(51 \%)$ to a single family. The tendering process was subject to allegations that the government trade union had colluded with the purchasers to frustrate a rival bid by workers.

PC maintained the external reporting system used previously but it became the exclusive preserve of the owning family. Two sets of financial records were maintained, one for the family, and one for "External reporting, which is for other shareholders, the bank, the tax authority and the Stock Exchange" (a senior accountant). Auditing appeared relatively light: a respondent commented, “Some informal transactions are kept in the 'IOU fund account' for irregular payments to trade union leaders and bribery of government and tax officials. These transactions usually appear under other headings in the annual reports".

The 1993-94 annual reports were not published until 1995. No reports have appeared since contrary to company law. ${ }^{6}$ As a company listed on the Dhaka Stock Exchange, PC must submit audited annual accounting reports to the Stock Exchange. Delayed publication meant minority shareholders, employees, creditors, financial institutions, and government agencies are severely disadvantaged. Three cases have been filed against PC to date: by the Securities Exchange Commission (SEC) for not 
holding annual general meetings; by banks for non-repayment of a loan; and by the Commissioner of Customs and Excise for not paying duty and taxes amounting to US\$26,000. Advocates of privatisation argue that private companies will try to show flawless reports to shareholders, creditors, and Stock Exchange officials to avert managers' fears of takeover. But this assumes a relatively strong capital market with access to relevant information. This was not apparent in PC. The external reporting problems raise important issues of equity, failures of regulatory control and enforcement, and potential market failures within the privatisation process.

Budgets and associated controls changed substantially after full privatisation. Computerised systems speeded up the supply of internal information. However, the researchers could find no professional cost accountant or system dedicated to providing cost information to managers. A budget committee prepared an annual budget but delegated financial budgets ceased. Financial information became a preserve of the inner sanctums of the family who exerted control downwards through imposed physical targets and exhortations to reduce costs mainly by taking out labour. Production managers exerted little influence - they were there merely to execute the family's commands.

Controls over employees became coercive. Increased control over workers was established by the increased use of sub-contracted, low paid, temporary labourers; widespread redundancies; the removal of trade union officials (bar a token puppet union); and the virtual elimination of collective bargaining. These actions were justified by a rhetoric of accounting (albeit invisible) imperatives such as cost savings, productivity, and profitability. The private owners established personalised and centralised controls through imposed arbitrary, physical budgets over a lowly paid but economically dependant labour force. Dreams of promotion or permanent employment allied to fears of instant dismissal for even minor misdemeanours secured worker effort. Such decisions were at the whim of the family. Employee resistance was minimal following the destruction of collective bargaining.

Policy makers' assumptions that private ownership would make controls more commercial were to a degree correct. Production and marketing systems were improved and speeded up, partly through 
computerisation. Budgetary controls became more flexible as they were focussed on market information rather than production as previously. Tighter work targets were imposed with effective monitoring. However, private ownership brought few more modern and compassionate managerial technologies such as individual economic incentive schemes or collective bargaining based on internal labour markets and an internal state. Nor was there evidence of any benefits of privatisation trickling down to labour: wages declined and an ill paid group of casual workers (often paid around one US \$ per eight hour shift) emerged. Wage levels, especially for unskilled workers, declined by approximately one half after privatisation. ${ }^{7}$ Approximately 700 workers and officers were made redundant upon privatisation and 310 new casual workers were gradually re-appointed thereafter. In 1994 the workforce (including casual workers) declined to 710 employees (615 manual and clerical workers and 95 officers). During the second visit to PC production managers revealed that the workforce remained at 1993-94 levels.

It may be too early to judge the effects of full privatisation upon PC's commercial performance, and any analysis is limited by the unavailability and dubious accuracy of accounting reports. Moreover, given the protection of PC from imports prior to privatisation, a simple comparison of results in different periods may be misleading. Nevertheless, our analysis is not flattering to the case for privatisation. The most recent annual reports (1993-94) show that sales increased slightly to TK. $292.43 \mathrm{~m}$. but PC incurred a loss of TK. $38.76 \mathrm{~m}$. (less than during the three years of partial privatisation but still the fourth worst on record). Return on capital employed remained negative and capacity utilisation remained low at $18 \%$. Value added distributed to government fell to TK. $37.6 \mathrm{~m}$. and, according to Dhaka Stock Exchange reports, PC's shares have been below par value since 1996.

The follow-up visit in 1999 confirmed that no accounts had been published after 1994's results. An accounting officer claimed that there had been no profit since privatisation, PC was currently breaking even, but it could become profitable despite intense competition. Production managers pointed out investments automating the Soap Department and refurbishing factory buildings. These managerial 
claims cannot be corroborated against documented accounts but, taken at their face value, they suggest that whilst commercial improvements have been made, $\mathrm{PC}$ is teetering on economic viability.

The researchers were unconvinced that privatising PC had facilitated development goals. Privatisation had not increased returns to society: PC's contributions to state revenue had declined; transparent external reports required by law had failed to materialise; there was evidence of untoward transactions affecting minority shareholders, creditors, and tax collecting institutions; and employment, wages, quality of working life, and employee protection through collective bargaining had all declined. Although internal controls had become more commercial, PC had not become a centre of modern, enlightened management practices: and there was little direct evidence of major investment or innovation, or increased profitability and growth. Overall, there was little evidence that privatisation had facilitated development goals either in the narrow financial sense of profitability (though obscuration in the accounts remains an issue), or with respect to broader criteria of increased employment, narrower income distributions, improved conditions of work, or increased state revenues.

\section{Post Privatisation Performance of PC: the World Bank Story}

The above sharply contradicts World Bank (1995) predictions that privatisation would improve the fiscal situation of Bangladesh, and improve the efficiency, productivity, costs and services of SOEs. A subsequent study commissioned by the World Bank in 1997 evaluated the performance of the thirteen companies privatised by the Privatisation Board from 1991 to 1996. This report contains a case study of PC since privatisation, which claims that: fixed costs for the main products fell by half; capacity utilisation tripled; sales almost doubled; and PC was profitable within one year of privatisation. Within two years, profits had increased by $113 \%$ resulting in "the overall financial health of the company appear[ing] sound, and its share price is stable in the stock market". An expansion programme had been undertaken and debt had increased by $50 \%$ but no repayments were made due to litigation by minority shareholders demanding interest payments on loans not specified in the tender document. It concluded that privatisation had run smoothly despite "the glacial pace and bureaucratic attitude of the 
Privatisation Board" and the two-stage privatisation was "ideal for privatization of sensitive SOEs". External employment growth had resulted and PC had "streamlined the inefficient work force. It made 455 of the employees redundant, paying them due compensations. This large-scale redundancy programme faced little labour resistance since it followed existing labour laws". Overall it observes that PC demonstrates how "even a profitable SOE can perform better under private ownership".

The researchers do not deny the economic problems of Bangladesh SOEs and it is difficult to unequivocally disprove the above claims given the lack of financial information about $\mathrm{PC}$ in the public domain. However, World Bank reports $(1995,1996)$ justifying privatisation emphasise the lack of financial accountability and transparency in SOEs, and their immunity from the financial discipline of markets and the scrutiny of legal institutions. Thus it is surprising that their study ignores whether predicted improvements in accounting and accountability materialised. Why can minority shareholders and creditors not receive the financial information legally due to them when the World Bank can?

The bases of comparison for PC's performance are misleading as full privatisation results are compared with the disastrous partial privatisation period, rather than that of public ownership. However, above all, we question the narrow criteria that the report adopted - namely profitability. The incorporation of other important development goals might temper the report's overall optimism to many readers. There was little evidence of the benefits of privatisation trickling down to labour or society. The World Bank report is myopic: development goals from privatisation disappeared from its agenda after the act.

\section{THE PERFORMANCE OF PRIVATISED COMPANIES IN BANGLADESH}

Faced with their different perceptions of the effects of privatising PC from the World Bank report, the researchers decided to examine the other companies privatised during 1991-1996. Four of the 13 companies (PC, CCCG, EBCM and DVOI) were privatised under the 51-49 Plan $^{8}$ because, according to interviews with Privatisation Board officials they were profitable. In 1988 they became public limited companies listed on the Stock Exchange. $49 \%$ of their shares were placed in private hands 
(34\% to public and $15 \%$ to employees) with the government retaining $51 \%$. This was not considered appropriate for the remaining 9 less profitable companies. When full privatisation began in 1992, the government holding of shares in the listed companies were sold through open tenders whereas the remaining 9 privatised but unlisted companies were offered in their entirety, again through open tendering. In four SOEs in this study (DVOI, Barisal Textile (5R), KTM, and MT) workers were made redundant before privatisation under the "Golden Handshake Project". Workers in the remaining companies under scrutiny were made redundant and paid off by the government.

The World Bank (1997) report gave glowing assessments of their achievements since privatisation, and recommended further privatisations. It claimed this would: improve the government fiscal situation; make companies more efficient; free resources for employment, investment, and productivity schemes elsewhere; and signal the government's commitment to private sector led economic growth. The remainder of the paper examines whether these claims were justified. In particular, did the privatisation of the thirteen companies improve: a) economic performance? b) social returns? c) labour conditions? d) transparent financial regulation?

Table One summarises data for each company pertinent to each of the above questions. Economic performance is measured in terms of sales, profits, ROA, and share performance. Social returns are measured by contribution to GDP and numbers employed. Contribution to GDP is based on corporation taxes paid (contributions such as custom duties and VAT are unavailable). Labour conditions are examined by total wages bill, per capita wages, and whether casual employment increased (this diminishes workers' rights within collective bargaining and employment law - under an Industrial Ordinance (1969) casual workers have no rights to trade union membership and collective bargaining agents (Government of Bangladesh, 1983, 1986). Transparent financial regulation was examined in terms of adherence to regulatory requirements. The four companies listed on the Dhaka Stock Exchange (PC, CCCG, EBCM and DVOI) must submit annual audited accounts and reports to external regulatory authorities that are available to the public, hold AGMs, and secure approval for payment of dividends. The remaining nine enterprises, as private limited companies, are 
not subject to Securities and Stock Exchange Rules but are subject to company law. Publishing accounting reports to the public is not mandatory but the preparation of annual audited accounts is (Section 181-209, Company Law, 1994). Private companies must submit annual reports to the Registrar of Joint Stock Company (Section 190, Company Law, 1994). Table Two summarises how each dimension changed after privatisation in each company. These results are examined company by company in more detail below.

[Insert Tables One and Two near here]

Chittagong Cement Clinker Grinding Company (CCCG) was nationalised in 1972, and in 1988 it was partially privatised becoming a listed public limited company. It was fully privatised in May 1992: the 51\% government holding of shares was sold to a family. CCCG, the biggest grinding cement mill in Bangladesh, has monopolistic power in a growing market.

The World Bank report claims that: "CCCG was profitable during partial and full privatisation. In 1988-89, the company met $111 \%$ of its target and made profits of TK. $95.02 \mathrm{~m}$. The new owners bought CCCG because it was a profitable concern in a prime location. The financial situation of CCCG improved significantly under private ownership. Between 1992-93 and 1995-96, production increased by $40 \%$ and sales revenue by $64 \%$. An expansion program is also underway.... [that] should triple production capacity by January 1999, making CCCG the largest cement producer in the country" (p.39-40).

Our findings were similar to those in the World Bank report. CCCG is one of the most successful privatised companies in Bangladesh. As Table One reveals, profits, sales, and ROA improved after privatisation: sales more than doubled, profit is nine times higher, and ROA increased almost fourfold. CCCG's shares with a face value of TK. 100 stood at TK. 1071.25 on $3^{\text {rd }}$ November 2001 , which is unusually high according to SEC records. Also, CCCG increased its contribution to the state from TK. 
$22.25 \mathrm{~m}$. to TK.144.21 m. Much of the improvement in economic performance came from wages decreasing from TK. 10.85 m. to TK. 7.65 m., indicating a marginal decrease in per capita wages.

The World Bank report asserts that industrial relations problems were few, as the new owners did not retrench workers and implemented the government Wage Commission to improve labour-management relations. Our observations corroborate this. The decrease of workers from 162 to 115 was achieved largely through voluntary redundancies with (for Bangladesh) generous financial benefits. However, interviews revealed that a many former workers were re-appointed on casual contracts after full privatisation. A manager commented: trade union activities such as strikes and demonstration had also significantly declined soon after ownership changes as trade union leaders were 'well handled' by the new management.

However, there were regulatory compliance and financial transparency problems. The ownermanagers concealed information to minority shareholders and illegally traded shares at inflated prices. Following an investigation the SEC filed a case against the owner-managers accusing them of concealing price sensitive information and violating securities regulations (The Daily Star, $3^{\text {rd }}$ November 2001). The SEC probe ${ }^{9}$ revealed that some of the accused had indulged in insider trading and manipulated CCCG share prices on the Dhaka and Chittagong Stock Exchanges. Thus, CCCG's economic performance is difficult to judge using stock market information. In summary, the favourable World Bank report on CCCG's commercial success since privatisation that brought benefits to the state must be tempered by recognition of job losses and failures in economic transparency and accountability.

The Eagle Box \& Carton Manufacturing Company Limited (EBCM) was established as a private company in 1961 to produce packaging materials for industrial and commercial concerns. It was nationalised in 1972, and partially privatised in 1988 as a listed public limited company. EBCM had 
been profitable as a SOE. Tenders for the government shares were invited in 1992 and the company was handed over to the successful bidders, a family, in December 1994.

The World Bank report (1997) claimed that: "Between 1991 and 1994, the annual turnover ... dropped by $20 \%$, sales revenues fell by $25 \%$, and losses increased by almost $2500 \%$. The new owners retrenched $35 \%$ of the employees to increase efficiency and lower costs. ... The entrepreneurs also carried out massive repair and maintenance projects to restore the productive capacity ... the new owners are instituting improvements and expansion programs to reverse the loss-making trend of the company. ... The owners believe they will see profits in the near future" (p.43-44).

Our investigations corroborate that EBCM was profitable under public ownership but made losses in the last three years of partial privatisation (1991-1994) averaging TK. $-0.2 \mathrm{~m}$. with a ROA of $-0.6 \%$. An interview with the owner-manager indicated that EBCM had not met the World Bank predictions of improved economic performance after privatisation. Table One shows annual sales of TK. $69.6 \mathrm{~m}$. during public ownership and partial privatisation dropped to TK. $54.8 \mathrm{~m}$. after full privatisation. EBCM remained unprofitable after full privatisation - average losses increased to TK. $22.4 \mathrm{~m}$., resulting in a ROA of $-17.4 \%$. Dhaka Stock Exchange reports reveal that EBCM's share price in October 2001 was half its par value. The World Bank report's calculation of EBCM's accumulated loss from full privatisation to 1997 of TK. $57.3 \mathrm{~m}$. by 1997 is plausible.

EBCM reduced its workforce from 192 to 131 after privatisation. Workers' wages of TK. 7.2 m. during public sector ownership increased to TK. 9.0 m. under private ownership. However, the latter figure includes managerial salaries (workers' and managers' wages are not differentiated in annual reports under private ownership). Thus the increase in per capita wages reported in Table One is unreliable. Once again, interviews revealed that private owners had appointed casual workers to replace permanent workers. The company accountant revealed that: "since a significant number of 
work force is now casually appointed, the trade union influences upon management are virtually absent under private ownership as casual workers are not allowed to be members of trade unions".

The World Bank report justifies the employment reductions by neo-classical canons of efficiency and productivity. But profitability has yet to be achieved and EBCM's contribution to social goals has declined. The government has received no corporation taxes since full privatisation whereas EBCM contributed TK. $0.6 \mathrm{~m}$. annually during the pre-privatisation period. In addition, EBCM stopped publishing annual reports since 1997-98 in defiance of Company Law, Stock Exchange requirements, and Securities Exchange rules. Control by family majority shareholders has resulted in negligible accountability and transparency. If the World Bank report (1997) and Dowla's (1998) predictions of EBCM becoming profitable were to materialise, this would not be signalled given no external accounting reports. In summary, it is difficult to point to the privatisation securing achievements on all, or almost all, of the development criteria.

Dhaka Vegetable Oil Industries Limited (DVOI) was established in Narayanganj as a private limited company in 1968 by the Adamjee Group to refine soybean oil and vegetable ghee. It was nationalised in 1972 and placed within the Bangladesh Sugar and Food Industries Corporation, and partially privatised in 1988. Despite running second-hand machinery with a normal productive life of 10 years for almost 30 years, DVOI was profitable from its inception to the latter years of partial privatisation. It was fully privatised in April 1993 being sold to a family business.

The World Bank report claimed that: 'though [DVOI] was unproductive and unsound, the company made notional profits until 1990-91 mainly because it enjoyed government protection. Acute financial problems began in 1990-91 when ... protection was removed ... facing competition in the market, the company had to sell oil at below the production cost. As a result, while the company had made a profit in 1990-91 of TK. 9 m., it incurred a loss of TK 39.5 m. in 1991-92. In 1992-93 the company incurred a further loss of TK. $37.5 \mathrm{~m}$. because it was not importing raw materials and production had stopped. 
The new owners took possession of the company in April 1993. The first challenge ... was ... to resume production at the factory. In the first two months ... the private owners were able to generate profits of TK. $2.8 \mathrm{~m}$. Though this was not enough to cover the losses incurred earlier in the year under state control, it was a marked improvement nonetheless. The new ownership was able to reverse the loss-making trend of the company initially, but has not been able to maintain its revenues and profits in recent years. Political unrest ... during 1995-96 has deterred production. Also, the withdrawal of government protection has resulted in a $30 \%$ decline in the company's market share, though it still maintains its command over the retail market. Higher competition has forced a $37 \%$ fall in capacity utilization, and a 33\% fall in production between 1991-92 and 1995-96. Finally, the higher price of raw materials on international markets has raised production costs by $17 \%$ for soybean oil' (p.55-56).

DVOI has incurred losses since full privatisation and the removal of protection. Table One shows average sales of TK. 543.6 m. pre-privatisation (including partial privatisation) dropped to TK. 171.3 m. following full privatisation. Average profit and ROA was TK. $12.5 \mathrm{~m}$. and $4.1 \%$ respectively during pre-privatisation. After privatisation, DVOI made an average annual loss of TK. $25.3 \mathrm{~m}$. resulting in an average ROA of $-8.4 \%$. DVOI's share price stood at TK. 22 on $3^{\text {rd }}$ November 2001, below its par value of TK. 100. DVOI has not recovered from its economic downfall since partial privatisation. Interviews with its owner revealed that he planned to sell the company.

The World Bank report claimed: "At the time of privatisation, the government had retrenched about 100 employees under the 'Golden Handshake' plan financed by ADB. The new owner retrenched another 100 employees, paying the due compensation, so that the labour force would be more efficient" (p.55). In contrast, audited reports filed with the Dhaka Stock Exchange during private ownership indicate only a marginal reduction in DVOI's workforce. Table One shows the average wages bill of TK $10.1 \mathrm{~m}$. pre-privatisation dropped to TK $7.0 \mathrm{~m}$. following full privatisation, producing a significant reduction of per capita wages. An interview revealed that there are now large numbers of casual workers, which may explain the dramatic decrease in wages. The Government has 
received no revenues from corporation taxes since full privatisation whereas it received TK. $20.1 \mathrm{~m}$. per annum during the pre-privatisation period. Once again, a family take-over resulted in a cessation of published annual reports and AGMs since 1998 for no discernible valid reason and contrary to external regulatory requirements.

Barisal Textile Mill (later named 5R Limited) was established in 1975 by the Bangladesh Textile Mill Corporation (BTMC) - a large state holding company. It consistently ran below capacity and made losses as a SOE. Consequently, it was closed down in 1993 and its workers were laid off under the 'Golden Handshake Project'. It resumed production in 1995 after its sale to the Khansons Group - a private unlisted company owned by a single family.

The World Bank report claimed that: "the new ownership has already reversed the loss-making spiral that the company faced from the day it was first commissioned. Losses fell by almost $90 \%$ by the second year of operation after privatization. Production costs fell, and capacity utilization doubled in the first year, and in February 1997 the mill reached its full production capacity of 25,056 spindles. A streamlining of the work force to $70 \%$ of its original size, with a new and effective management has raised productivity. While the company is not generating profits as yet, the owners are confident that they will be able to show a profit by 1999, provided there are no unforeseen external shocks. Expansionary changes have also been instituted.” (p.37-38).

World Bank predictions have failed to materialise: annual reports (up to year 2000) supplied by the company reveal that $5 \mathrm{R}$ has made a profit in only one year of six as a private operation. Preprivatisation sales averaging TK. $76.4 \mathrm{~m}$ p.a. increased to TK. $117.1 \mathrm{~m}$. after full privatisation. The negative average profit/ (loss) and ROA of TK. $-22.3 \mathrm{~m}$. and $-24.1 \%$ respectively during public ownership remained negative but decreased under full privatisation to TK. $-2.6 \mathrm{~m}$. and $-3.0 \%$ respectively. 
The World Bank report claim that reducing the workforce by $30 \%$ had helped raise productivity is confirmed by our research. Numbers employed initially decreased: more than 200 workers were retrenched after privatisation. Employment is now similar to pre-privatisation levels but interviews revealed that many workers were now on temporary contracts with decreased wages. The latter was confirmed in company reports: per capita wages fell by nearly one half, from an annual average of TK. 19.2 m. under public ownership to TK. 7.4 m. after privatisation. The state and the Asian Development Bank financed this deterioration in labour conditions. As a manager commented: "We do not have any trade union problems as all workers including trade union leaders were retrenched before privatisation under the ADB sponsored Golden Handshake Programme”. Interviews intimated that private ownership had brought harsher regimes of control, more casual workers, reduced workers' wages, and curtailed trade union activities. There were no collective bargaining agents elected from workers, contrary to the Industrial Relations Ordinance, 1969. 5R still makes no direct contribution in corporation taxes to state coffers. However, 5R has regularly produced audited accounting reports under private ownership though there are suspicions about their validity and accuracy. For example, this company has made accumulated losses of TK. 13 m. since privatisation, but the owners refuse to sell the company. There have been indications of increasing sales revenues and production recently but $5 \mathrm{R}$ still reports losses despite a huge reduction of wages. In summary, though the reported data still reports losses the company has shown improvement since privatisation but this has yet to yield social returns in terms of taxation, higher wages and employment, or conditions of employment. Legal accountability has been observed.

Kishoreganj Textile Mills (KTM), like 5R, was established in 1975 by BTMC only to become loss making. In 1992 the government made its workers redundant under the 'Golden Handshake' project but as a government official revealed: "Government could not pay off all dues to redundant workers timely as the ADB later withdrew their sponsorship". KTM's long-term liabilities of TK. $22.2 \mathrm{~m}$. were paid from the same fund (World Bank, 1997; Dowla, 1998). In May 1993 the government invited 
tenders for the business resulting in its hand over to a family in 1994. The new owners were in the garments business and they believed KTM could generate profits immediately.

The World Bank (1997) claimed: "In 1991-92, [KTM] incurred loss of TK. 6.4 m. ... quarter of the previous year. Capacity utilization fell by 16\% from 1990-91, and production target achievement fell by over $25 \% \ldots$ sales revenue and total income both fell by $66 \%$. After the hand-over ... the new owners were able to begin trial production by February 1995. The new owners invested about TK. 20 m., entirely self-financed, in the mill to modernize and repair the machinery and premises" (p.45). The report claims that from privatisation until $1997 \mathrm{KTM}$ had accumulated losses of TK. $21.6 \mathrm{~m} .$. The report declares that: "Though the company is not generating profits as yet, the new owners are hopeful that they will be able to turn the situation around in the next three to four years by raising productivity, culling costs and increasing production" (p. 46).

These financial expectations did not materialise according to unaudited annual reports provided by KTM's accountant. Before privatisation KTM registered an average loss of TK. 18.7 m., which increased to TK. 22.4 m. after privatisation. Sales and ROA dropped from TK. $91.3 \mathrm{~m}$. and $-12.9 \%$ to TK. $79.9 \mathrm{~m}$. and $-19.5 \%$ respectively. Before privatisation KTM employed 993 workers, after privatisation it had 580. The Government made major redundancies before full privatisation but many workers were re-appointed by the new owners, mainly on casual contracts with lower wages. The wage bill dropped from TK. $22 \mathrm{~m}$. to TK. $11.5 \mathrm{~m}$, indicating a marginal decrease in per capita wages. The accountant revealed that: trade union resistance is not a major problem now as it was under the public sector period mainly because of all trade union leaders and workers were made redundant before the new owner took over. Selective appointment was made by the new owners to avoid trade union influences upon management.

KTM still did not contribute corporation taxes to the government exchequer after privatisation. No audited accounts or filed annual reports required under company law could be traced. Accountability 
and transparency did not appear to be a priority for the owner. The main office was locked all the time but the researcher discovered a part-time accountant who dealt with all accounting issues in the evening for this large company. When interviewed he could only supply un-audited financial statements: it could not be firmly established whether these were audited. Yet, despite KTM's losses, its owner does not intend selling it or suspending operations. This and the lack of attention to financial matters raise concerns over the validity of the accounting reports supplied and the accountability of this company. On the face of it privatisation has brought worsening commercial performance, lowered benefits to employees, no taxation, and less transparency. If the accounting data supplied is accurate there seems no limit to the bountifulness of the owners or their commercial optimism.

The Kohinoor Spinning Mills (KSM) was also established by BTMC in 1975 and was not profitable as a SOE. The government closed it in 1993, making all workers redundant. In 1995, after tendering, KSM was sold to an owner of several textile companies who, when interviewed, revealed that he bought the company as it had few liabilities. KSM resumed operations in June 1996.

The World Bank report comments how: "the private owners have succeeded in turning the company into a profitable concern within a year. Production has increased by about $22 \%$ and per unit costs have fallen. Capacity utilization has increased and stands at $60 \%$ of the mill's rota/potential capacity. Revenue has rocketed by $300 \%$, compared to $1992-93$. However, costs have also increased with an increase in long-term debt to the banks. Still, a profit of TK. $1.90 \mathrm{~m}$. was made in 1996. Expansion programs are being implemented and planned as well. Already, a UK and Cyprus based firm has made an offer that will ensure the sales of the company for the next ten years. This has made it imperative for the new owners to expand its capacity ... They are now in the process of buying new machinery that will double the production capacity by the end of the year. Ten Pakistani experts have been brought in to ensure this expansion. Moreover, the entrepreneurs are also negotiating with foreign investors to arrange US\$30m. to renovate the factory and expand its capacity. The owners hope that these measures will raise production of the company and alleviate the financial constraints" (p.49-50). 
In the absence of any audited accounts our analysis rests upon the financial statements up to 1999 supplied to us by the owner on a newly typed piece of paper. These and an interview with the owners revealed that KSM had continued to make losses after privatisation and there had been no expansion programmes contrary to the World Bank report. Indeed, there were only two employees in the main office. The owners alleged that because of their connections to opposition parties, banks would not grant them loans. The World Bank report claimed that: "A new workforce of 550 people was hired ... about $47 \%$ of the previous workforce ... retrenched by the government". (p.49). However, it was ascertained that workers employed dropped from 835 to 470 , and the wages bill dropped from TK. $20.1 \mathrm{~m}$. to TK. $12.3 \mathrm{~m}$. after privatisation. This indicates a marginal increase in per capita wages. No contributions in corporation taxes have materialised. Lastly, accountability and transparency have declined as the owners have failed to produce any audited reports since privatisation. Whatever, production ceased in 1999 and the owners, rather than turning the firm around as the World Bank claimed, are trying to sell it.

The Style Fabrics Embroidery Limited (FEI), established as Jofiane Febrics in 1969, was nationalised and placed within the BTMC in 1979. It made losses ever since, never achieving its production capacity of 240,000 yards per year. In 1993 FEI was closed and the government retrenched all its workers. A family bought it by tender to in 1995 but because of shortages of skilled workers following the redundancy programme the new owner could not start production until January 1996.

The World Bank report revealed that initially FEI could, 'use one machine only, and it produced about 28,000 yards of embroidered cloth in the first year. The company incurred a loss of TK. 3 m. that year. Its long-term liability, meanwhile, has grown by another $20 \%$ to become TK. $9.46 \mathrm{~m}$. Besides, it has received a project loan of TK $8.8 \mathrm{~m}$. from Sonali Bank, which it is paying back now in instalments. Recently, the entrepreneurs have launched an expansion program ... to meet the healthy demand for 
its products. Thus, the company should be able to raise itself out of the hole, and begin to make profits in the near future' (p. 53).

The chief accountant, when interviewed, was unable to produce audited accounts: the data summarised in Table One relies on books of accounts (unaudited) supplied by the accountant. This revealed that FEI is still not making profits. From 1996-97 to $1997-98$ sales revenue increased from TK. 0.8 m. to TK. 6.3 m. but no profits had materialised. After privatisation average losses were cut from $2.6 \mathrm{~m}$. to $0.8 \mathrm{~m}$. resulting in ROA changing from $-25.8 \%$ to $-7.9 \%$, employee numbers decreased by $6.7 \%$ (from 46 to 42 ) but the wages bill dropped by 33\% (from TK. $2.1 \mathrm{~m}$. in 1993-94 to TK. $1.4 \mathrm{~m}$.), indicating a decrease in per capita wages of nearly one third. Interviews revealed that most workers are now on short-run temporary contracts and are ill paid. Contributions to state coffers remain at zero. It was impossible to definitively ascertain whether the company had complied with external financial regulations after privatisation though the suggestions were that privatisation has not brought increased financial transparency and accountability. If the data supplied is correct then the result of privatising FEI is similar to KTM: losses have been reduced but with no discernable improvements for labour or society. Once again privatisation appears to attract owners noted for charity rather than entrepreneurship. The more cynical have suggested tax evasion might be a better explanation for the continuance of these businesses.

Madaripur Textiles Limited (MT) was established as a SOE by BTMC in 1976. From the start the mill incurred huge losses. In 1993 the government closed it, making all workers redundant with finance from the Golden Handshake Programme. In 1995 the company was sold to a family and it recommenced operations under a new name - Madaripur Spinning Mills.

The World Bank researchers could not access this company but we contacted the owner and arranged interviews with the chief accountant. He proved unwilling to divulge 'sensitive figures' such as profit and wages' or to grant access to any audited accounts but he was willing to provide information on sales, production, numbers of workers, tax and duties paid. The performance of MT in Table 1 is 
based on this limited data, supplemented by observations. This suggests the firm is performing better since privatisation. Average annual sales of TK. $115 \mathrm{~m}$. increased to TK. $136.3 \mathrm{~m}$. after privatisation. However, in the absence of data on profits and investments or audited accounts, it is difficult to draw valid conclusions about the economic performance of MT. Employment declined after privatisation. The average of 795 workers employed before privatisation dropped to 677 after privatisation. The new management stated that the wages bill had been reduced but they declined to provide information on wages believing it to be a sensitive issue, though the accountant revealed that a significant number of casual workers were appointed after privatisation. He declined to comment on changes of worker's rights such as joining a trade union and election of collective bargaining agents after privatisation. He claimed that MT has paid, on average, TK. 28.2 m. p.a. to government in corporation taxes. On the face of it MT would appear to have been a relatively successful privatisation. However, the validity of the data may be unreliable. It relies on the chief accountant's verbal responses and, although he claimed that company accounts were audited regularly, there is no way of accessing them or confirming their audit, contrary to Company Law, 1994. Once again this signifies the lack of transparency and accountability in privatised companies.

Bangladesh Cycle Industries Limited (BCI) was established in 1957 by a Pakistani entrepreneur. In 1972 it was nationalized and placed within the Bangladesh Steel and Engineering Corporation. Until 1980 it was normally profitable but from 1981 to 1992 it made accumulated losses of TK. $110.8 \mathrm{~m}$. The government closed it in 1992 and met the costs of making all its workers redundant and settling its liabilities. In January 1993 BCI was placed on the privatisation lists and was sold to the Meghna Group of Companies, the highest bidder in June 1994, resulting in its hand over in August 1994.

The World Bank report stated that: "In 1992-93, the company was utilizing about $8 \%$ of its production capacity, incurring a loss of TK. $15.4 \mathrm{~m}$. in 1992-93, its fixed assets stood at only TK. $3.1 \mathrm{~m}$. and long term liabilities totalled TK. 9.7 m., having rocketed by 500\% in one year. In sum, the Meghna Group had to accept large additional expenses and charges as a result of the delays and mismanagement of the Privatization Board and this has hampered the functioning of the company and placed a large 
financial burden on it. The financial situation is, however, alleviated somewhat because the government absorbed the long liabilities of the company. The Group hopes to produce commercially by August 1997 and to generate profits from the very first year" (p.41-42).

It is doubtful whether this company had commenced operation by 1997 after four years of privatisation. No data on the company could be accessed as its main office or accountants (if there are any!) could not be located.

The three other companies privatised during 1991-96 were Quantam Pharma (QP), Sinha Textile (ST) and Hamidia Metals (HM). ST and QP refused to provide any data to the researchers. The World Bank report did not investigate ST because of access problems but it did provide some limited information about QP. However, this project managed to collect further information about QP and ST from other sources.

Quantam Pharmaceuticals (the new name of Squibb (Bangladesh) Limited) was established as a joint venture in 1966 by E.R Squibb \& Sons Inc. of the USA and the East Pakistan Development Corporation. It became wholly state owned in 1972 and continued to make losses. In May 1994 it was sold to an entrepreneur. The World Bank report claimed that QP had been closed since privatisation due to an ongoing modernisation programme. The researchers could find no trace of any production during 2001, nor could any of its previous products be found on the market. Also, audited accounting reports required from a private company under company law had not been filed. A formal inquiry on whether they had submitted any accounts to the tax office was unsuccessful, as information regarding private companies' tax position is not publicly available in Bangladesh. The existence of QP could not be confirmed.

Sinha Textile was sold to a family in 1994 becoming registered as a private limited company renamed Sharmin Textile (ST). Whether regular audited accounting reports existed could not be confirmed as access to this company was denied. Observations during a visit to its premises indicated that this 
company was active, having been merged into a group of companies owned by the same family. The firm is well known to professional accountants as they employ a large number of professional cost accountants but this did not appear to improve the company's accountability or transparency (Ahmad and Des Nicholls, 1994).

The World Bank report indicated that HM had been closed since its privatisation in 1994 - unable to resume operations because of legal problems. The report noted: "the owner refuses to pay the remaining balance (payment to government for sale proceeds) on the grounds that the company was not handed over in a timely manner. ... to make it worse, Sonali Bank (one of the leading state owned banks), which lent about TK. $6.3 \mathrm{~m}$. to HM in early 1980s, called for auction for the company in May 1997". The World Bank report conceded that the research on HM was "based on insufficient, in some cases inaccurate, information. Adequate cooperation of the concerned entrepreneurs could not be obtained" (p.51). Whatever, the subsequent research could not progress matters as it could not locate the existence of the company at its original address. HM has vanished.

Finally, we wish to turn to aspects of the privatisation process, namely the two-stage privatisation process (from SOE to partial privatisation under 51-49 plan to full privatisation) and the determination of selling prices. All four listed public limited companies that underwent partial privatisation were profitable until this occurred. The dual ownership under the '51-49' plan resulted in severe organisational problems. Whatever, there was a dramatic decline in the performance in all the partially privatised companies except CCCG. Yet, the World Bank report (p.ix) claimed: "the two-stage privatisation process (the 51-49 plan), initiated under the industrial policy, 1986, could be the ideal for privatisation".

[Insert Table Three near here]

Table three compares the actual selling price of the Bangladesh companies studied here with, where available, their initial valuation (neither the researchers nor the World Bank could access the estimated value of seven firms). The World Bank report claimed that the companies were over-valued though, 
according to an interview with a Privatisation Board official, chartered accountancy firms such as Price Waterhouse Coopers sometimes determined valuations. However, the Board had no obligation to accept these valuations. In most cases it established the selling price after considering responses to first tender calls. Often, low prices were set at the first tender call, for example the Privatisation Board set the price of FEI below its estimated value. Yet eight of the privatised companies under study were sold after the first tender. The lack of transparency and accountability, or clear guidelines for fixing sale prices lower than valuations raises doubts over the economic basis of the prices of privatised companies were sold for, a point also expressed in the World Bank report (1997). Moreover, not only did the state bear the cost of preparing companies for privatisation but, according to a Privatisation Board official: We failed to realise sales proceeds of some privatised companies. Besides, often the government of Bangladesh had to take the responsibilities of long terms loans before selling public sector enterprises. Eventually sales proceeds leave nothing for the government's exchequer. The evidence that the proceeds from privatisation added to government revenue is unconvincing.

\section{Summary}

The World Bank report (1997) concluded that: “... seven [companies] had made an average profit of $185 \%$; overall employment in nine had declined by $18 \%$; labour productivity had increased by $71 \%$ in three; and total sales had increased by an average of $71 \%$ in seven (including PC). There has been, however, much variability, in their production figures. Five firms saw an average fall of production of 13 per cent and the remaining three raised production by 91 per cent" (see also Dowla, 1998, p.56-57). The report noted that they had: "experienced a substantial flow of investment since privatisation, Besides acquiring these companies at a cost of TK. $936.3 \mathrm{~m}$., the private entrepreneurs already spent TK. $635.7 \mathrm{~m}$. for renovation and replacement of the inherited machinery and additional TK. $1808 \mathrm{~m}$. is being invested currently." The report attributed poor performance by some companies to exogenous factors, such as political instability, worker unrest and change in government policies (see also, Dowla, 1998, p.57). Overall the report claimed company performance had improved significantly, they had experienced substantial investment since privatisation, and its results demonstrate the inability of the 
state to run companies productively. It concludes that: "The case for privatisation is clear - all is not wrong with privatisation as some tend to believe" (World Bank, 1997, p. 8; Dowla, 1998).

The authors have reservations about the World Bank claims. Firstly, there are concerns about the validity of data. Accurate reliable information about privatised companies is difficult to obtain and that available needs to be treated with caution. This makes it difficult to prove or disprove claims about their economic performance. The World Bank report mostly relied on hopes and aspirations of owners rather than hard facts. In parts its information contradicts the few published annual reports that are available. The World Bank evidence for the success of privatised firms relative to their performance as SOEs is questionable. This is attested in Table four that summarises this research's conclusions on the postprivatisation performance on the key indicators identified earlier.

[Insert Table Four near here]

The World Bank report (1997) claimed profits had improved after full privatisation and fresh investment had materialised. The accounting information garnered by the authors revealed more variable results. CCCG had increased its profits; MT verbally claimed to be profitable; KSM reported a period of profitability but has since ceased production, and 5R and FEI, whilst both remaining unprofitable have decreased losses. All the remaining companies either declined to reveal information or claimed to be unprofitable. Three companies have ceased production or never resumed it after full privatisation and two more are struggling and planning to sell their companies. The World Bank report's claims of TK.1808 m. planned investment largely consists of KSM's planned investment of TK. 1332 m. planned for 1997, which never materialised and the company closed in 1999. Performance in terms of sales revenue was variable, increasing in CCCG, 5R, FEI and MT but decreasing in PC, EBCM, DVOI, and KTM. KSM and QP had shut: HM and BCI had vanished and presumably have shut. ST proved impenetrable with respect to getting data but appeared to be in production. The share prices of the four public companies listed on the stock exchange fell below par with the exception of CCCG. However, CCCG's share prices are questionable as the Dhaka Stock Exchange has filed a court case against its 
owner-managers for over-inflating share prices. Nevertheless, only CCCG can be identified with any confidence as a commercial success in terms of sales and making positive profits and ROI. Other privatised companies fell short of expectations contrary to the World Bank (1997)'s findings. Overall, the World Bank's claims of superior performance of these companies after privatisation are dubious at best and misleading at worst.

The research also questions the narrowness of the criteria used by the World Bank report, namely profits to the neglect of other development goals, namely social returns, employee conditions, and financial transparency. Table One presented data on the performance of companies under both public and private ownership on each dimension and Table Four tentatively judges whether performance improved, deteriorated, or cannot be ascertained. Table Four shows no privatised companies improved their contributions to state coffers after privatisation except CCCG and possibly MT. In all cases the number of workers and the wages bill declined after privatisation (MT did not provide suitable data). Per capita income decreased in all cases where data was forthcoming except possibly KSM. Given the widespread temporary employment of workers denied rights and protections under the Industrial Ordinance, 1969 (see Government of Bangladesh, 1983, 1986) it is likely that conditions for labour declined with respect to collective bargaining and employment rights. The consequences of this are illustrated in the intensive case study of PC (see Uddin and Hopper, 2001).

The last question is whether the increased financial transparency and accountability underpinning economic theories of privatisation and structural adjustment programmes actually materialised. Only CCCG, of the four privatised companies listed on the stock exchange (PC, CCCG, EBCM, and DVOI) appeared to audit its accounting reports, publish them, and hold regular annual general meetings after privatisation, despite this being mandatory under Stock Exchange and Securities Exchange Commission rules (1987) and Company Law (1994). PC, EBCM, and DVOI all stopped publishing accounting reports soon after full privatisation and appeared to have stopped auditing their accounting reports by 1998. The other nine privatised companies were private limited companies subject to Company Law, 1994, which requires submission of annual audited reports to the Registrar of Joint 
Stock Companies. Most companies appeared not to do so, though it was impossible to confirm this definitively. The privatised companies' unwillingness to reveal financial information may well be due to a tax avoidance culture (Perera, 1986; Humphrey, 1990), brought about by weak regulatory frameworks and enforcement. This also raises further concerns about the veracity of financial data revealed and difficulties of using it to evaluate policy. Donor agencies took pains to create an "enabling environment" for privatisation in Bangladesh by financing widespread redundancy programmes in SOEs, cancelling their debts, and providing incentives for investors. Given the cost of this, it is surprising that the report pays so little attention to structures of financial regulation that facilitate open, transparent capital markets (Uddin and Hopper, 1999, World Bank, 1995). Despite improvements in accounting and accountability being central to their policies, policy makers and development economics researchers, as in this instance, often neglect to investigate whether they materialise after privatisation or during the privatisation process.

The World Bank report (1997) and Dowla (1998) implies that private ownership has improved management. The report states: "All but two companies were brought by entrepreneurs who have previous experience in the line of business making them better able to make sound management decisions. In most cases efficient and experienced staff have been hand picked by the new owners. In all companies management and production efficiency has increased largely due to the marked reduction in the size of labour force and prudent economic decisions" (World Bank, 1997, p.26; see also Dowla, 1998; p58). The hand picking of staff and workers is plausible following the results of the intensive case study of PC. This revealed that the new owner-managers brought a tight, direct, informal control system reinforced by arbitrary patronage with respect to employment and promotions. This was made possible by large redundancy programmes and the appointment of casual sub-contracted workers. Interviews with accountants, managers and owner-managers in other privatised companies also revealed reorganisations of employment relations involving the increased use of sub-contracted, low paid, temporary labourers, widespread redundancies and the virtual elimination of collective bargaining, which enabled the new owners to institute direct and harsh control regimes for workers. ${ }^{10}$ Whether this constitutes improved management is debatable. 


\section{CONCLUSIONS}

This paper has questioned World Bank claims that privatisation improves management controls, commercial performance, and development, and it has cast doubt on the World Bank's own assessment of a set of privatisations. Whilst the authors do not deny the need to reform Bangladesh SOEs, major shortcomings of the denationalisation process are raised. Even on the World Bank's narrow criteria of profitability, the performance of privatised firms was disappointing. However, above all, the paper questions the World Bank's focus on profitability to the neglect of employment conditions, including trade union and individual rights; social returns; and financial transparency and accountability to external constituents. Development aims should extend beyond commercial criteria to issues such as poverty alleviation, narrowing income inequalities, and the quality of work experience. Sadly, according to the analysis above, the privatisations under scrutiny also appeared to be a relative failure viewed against these broader criteria.

Accounting researchers should be suspicious of mono-variable linear explanations of control problems based on types of ownership (i.e. public or private) and instead seek explanations incorporating the complex factors that surround firms and society, and forms of economic regulation. For example, the type of private ownership following privatisation can be crucial for its outcome (Scott, 1985, Espeland and Hirsch, 1990) and the nature of accounting (Ansari and Bell, 1991). Bangladesh has a small capitalist class concentrated in small, family-owned merchant businesses rather than manufacturing that relies on personal transacting, is risk-averse, and is under-capitalised. This frustrates the rapid development of the form of market capitalism sought by external aid agencies and hasty reform has unanticipated and undesirable effects. When such a small capitalist class transacts with unaccountable politicians operating in a weak state with poor financial regulation and legal enforcement, and weak capital markets, it is a breeding ground for crony capitalism associated with familial transacting, patronage, and irregular financial practices. This produces non-transparent placements of public assets into private hands at prices unrelated to valuations, financed by state institutions with little expectation 
of repayment. It is little wonder that transparent external reporting fails to occur, even at the levels required by legislation. Within the enterprise this tends to produce harsh internal controls rather than the systems of large, institutionally owned and professionally managed global companies. As the World Bank Vice-President of South Asia, Mr Nishimizu admitted, "Corruption and poor governance stood in the way of a much faster growth and poverty reduction, corroding the nation's economy, finances, and institutions. ... Too many, even in the private sector, continued to abuse the public's trustgiving the sector a bad name and prompting a negative connotation of the word "privatisation" (The Daily Star, March 14, 2002).

In Bangladesh, the problems of SOEs mostly emanated from political intervention and patronage made possible by the low democratic accountability of politicians and pervasive corruption. Political and bureaucratic interests recognise the threats to their power and patronage posed by privatisation (Cool, 1986; Cook and Kirkpatrick, 1988). Some may resist changes but, given the external pressure, most see this as spitting in the wind. Instead they are subtle and try to reassert their influence by different means such as regulatory capture, or by furthering their own interests in the privatisation process. The essential point is that changing ownership without first strengthening accountability and governance, and legal and regulatory enforcement, and protecting constituencies other than capital, merely resurrects the very practices it aimed to abolish, albeit it in a new guise. It is unwise to assume that efficient forms of accounting will automatically flow from policies increasing the role of the private sector. Accounting is socially and politically determined, and cannot be left to markets, being an important pre-condition for market functioning. Thus, accounting reform is a crucial but neglected component of effective development policy. When neglected the result is perverse and ineffective reforms as noted in the above cases of privatisation.

Underlying this above is a more fundamental debate about the effectiveness of structural adjustment programmes in LDCs. In contrast to the optimistic claims of neo-classical development economists and proponents of market-based reforms, more radical political economists argue that they mark further subjugation of LDCs. For example, Burawoy (1985) argues that in LDCs "pressures from 
agents of international capital for market reforms, cause hegemonic regimes [based on state central planning and state ownership of major commercial companies] to decline. Instead economically peripheral states often turn to programmes of economic liberalisation based on export processing zones, privatisation, and touting the attractions of cheap, economically weak, unprotected labour to foreign capital". Burawoy $(1979,1985)$ argues that this brings new despotic regimes of control in LDCs based "not merely on the subjection of workers but on the mobility of capital ... workers must accede to coercive and unilateral management control under the threat of the relocation of capital. This is especially acute in LDCs given the poverty of their states and populace". Similarly, Martin (1995) argues that privatisation in South Africa is unlikely to bring "black economic empowerment" and it guarantees little except that a few people get very rich, or 'economically empowered' (p.741; Catchpowle and Cooper, 1999). This paper gives support to such concerns.

The suspicion is that privatisation in Bangladesh may have redistributed power and wealth to some of the new owners, as in other countries (be they developed or less developed) (Shaoul, 1997; Martin, 1995). The paper provides support to critics of structural adjustment policies in LDCs who allege that they lead to crony capitalism and despotic control regimes for workers (Burawoy, 1985, 1979; Uddin and Hopper, 2001). Above all it shows how the IMF, World Bank and richer capitalist states have provided the technical infrastructure and organisational capacity to execute a neo-liberal privatisation agenda with insufficient regard for regulatory issues and protection of employees (Catchpowle and Cooper, 1999; Martin, 1995). The obsession with market relations has led to progress being assessed through narrow indicators such as growth of GNP rather than other worthy development goals. ${ }^{11}$ Also there has been insufficient regard for how contextual factors may affect market solutions in Bangladesh. Poverty, unequal income distribution, low purchasing capacity, unemployment, political instability, and the consequences of colonialism, all impact upon privatised companies leading to questionable valuations, placements to familial or political colleagues, harsh regimes of control, weak financial regulation and accountability, and financial malpractice (Uddin and Hopper, 2001; Wickramasinghe, 1996). These cases of privatisation in Bangladesh are not unique. It is happening again and again around the World. 


\section{References}

Abu-Nassar, M and Rutherford, B, A., 'External Users of Financial Reports in LDCs: The Case of Jordan”, British Accounting Review, Vol.28, 1996, pp.73-87.

Adam, C., Cavendish, W. and Mistry. P. S., Adjusting Privatization - Case Studies from Developing Countries (London: Currey, 1992).

Ahmad, M., "Wither Public Enterprise", Political Economy, Journal of Bangladesh Economic Association, Vol.2, No.1, 1976, pp.3-12.

Ahmad, M., "The Historical Perspective of Public Sector Enterprises in Bangladesh", The Journal of Management Business and Economics, Dhaka: Institute of Business Administration, Vol.2, No.3, 1976a, pp.252-294.

Ahmad, M., (1993), "Public Enterprise Reforms, Employment and Productivity" in R. Islam and W.K. Blank (eds.), Social Dimensions of Economic Reforms in Bangladesh, ILO-ARTEP.

Ahmad, M., (1994), "The Impacts of Privatization on Distributional Equity in Bangladesh", in Ramanadham, V.V. (ed.), Privatisation and Equity (Routledge: London, 1994).

Ahmed, K and Nicholls, D., 'The Impact of Non-financial Company Characteristics on Mandatory Disclosure Compliance in LDCs: The Case of Bangladesh", International Journal of Accounting, Vol. 29, 1994, pp.62-77.

Alam, M., "The Budgetary Process in Uncertain Contexts: A Study of Public Sector Corporations in Bangladesh", Unpublished PhD Thesis, 1990, London School of Economics.

Alam, M., "Budgeting Process in Uncertain Contexts: A Study of State-owned Enterprises in Bangladesh", Management Accounting Research, Vol.8, No.1, 1997, pp.147-168.

Ansari, S.L. and Bell, J., "Symbolism, Collectivism, and Rationality in Organizational Control", Accounting, Auditing and Accountability Journal, Vol.4, No.2, 1991, pp.4-27.

Arnold, P. \& Cooper C., “A Tale of Two Classes: The Privatisation of Medway Ports" Critical Perspectives on Accounting, 1999, pp. 127-152.

Ayub, M and Hegstad, S., "Public Industrial Enterprises: Determinants of Performance", World Bank Industry and Finance Series, (Washington DC, No.17, 1986).

Bangladesh Bureau of Statistics, Statistical Yearbook of Bangladesh, (Dhaka, Bangladesh: Statistical Division, Ministry of Planning, 1993).

Burawoy, M., Manufacturing Consent (University of Chicago Press, 1979).

Burawoy, M., The Politics of Production (London: Verso, 1985).

Catchpowle, L. \& Cooper, C., "No Escaping the Financial: The Economic Referent in South Africa", Critical Perspectives on Accounting, Vol. 10, No. 6, 1999, pp.711-746.

Cook, P., "Liberalisation in the Context of Industrial Development in Less Developed Countries", Manchester Discussion Papers in Development Studies (University of Manchester, 1986, No.8602). 
Cook, P. and Kirkpatrick, C., "Privatisation in Less Developed Countries", in Cook, P. and Kirkpatrick, C. (eds), Privatisation in Less Developed Countries, pp.3-31 (New York: Harvester Wheatsheaf, 1988).

Cook, P. and Minogue, M., "Waiting for Privatization in Developing Countries: Towards the Integration of the Economic and Non-Economic", Public Administration and Development, Vol.10, No.4, 1990, pp.389-403.

Cook, P. and Kirkpatrick, C., (eds) Privatisation Policy and Performance: International Perspectives (New York: Harvester Wheatsheaf, 1995).

Craig, J., "Evaluating Privatisation in Zambia: A Tale of Two Processes", Review of African Political Economy, London, 2000, pp.357-366.

Dowlah, C.F., "Benefits of Privatization: Evidence From State-Owned Enterprises Privatized in Bangladesh During 1991-1996”, Asia Pacific Development Journal, Vol.5, No.2, December, 1998, pp.45-67.

Donald, D. \& Hutton, A., "Public Purpose and Private Ownership: Some Implications of the "Great Capitalist Restoration" for the Politicisation of Private Sector Firms in Britain", Journal of Economic Issues, Vol. 32, No. 2, June 1998, pp. 457-464.

Espeland, W.N and Hirsch, P.M., "Ownership Changes, Accounting Practices, and the Redefinition of the Corporation", Accounting, Organizations and Society, Vol.5, Nos.1/2,1990, pp.77-96.

Flemming, J. \& Mayer, C., "The Assessment: Public-Sector Investment", Oxford Review of Economic Policy, Vol. 13, No. 4, Winter 1997, pp. 1-11.

Funkhouser, R and McAvoy, P.W., "A Simple Observation on Comparative Prices in Public and Private Enterprise”, Journal of Public Economics, Vol.11, No.1, 1979, pp.353-368.

Furubotn, E.G and Pejovich, S., "Property Rights and Economic Theory: A Survey of Recent Literature", Journal of Economic Literature, Vol. 10, No.4, 1972, pp.1134-1162.

Goodman, J. B. \& Loveman, G. W., "Does Privatization Serve the Public Interest?" Harvard Business Review, Vol. 69, No. 6, November-December 1991, pp. 26-38.

Ghafur, A., "On the Nationalised Industrial Sector Controversy", Political Economy, Journal of Bangladesh Economic Association, Vol.2, No.1, 1976, pp.5-10.

Government of Bangladesh, "President's Order No.27. The Bangladesh Industrial Enterprises (Nationalisation Order)", The Bangladesh Gazette Extraordinary, Ministry of Law and Parliamentary Affairs, (Govt. of Bangladesh, 26 March, 1972).

Government of Bangladesh, Contract Labourers (Dhaka: Bangladesh, 1986).

Government of Bangladesh, Industrial Relations Ordinance 1969 (Dhaka: Bangladesh, 1983).

Government of Bangladesh, Guidelines on the Relationship between Government and Autonomous Bodies/Corporations and the Autonomous/Corporation and Enterprises under Them (Cabinet Secretariat, Cabinet Division, May, 1976).

Hanke, S.H., "The Privatisation Option: An Analysis", Economic Impact, Vol.3, No.55, 1986, pp.1420. 
Hemming, R. and Mansoor, A.M., Privatisation and Public Enterprises (Washington DC: IMF Occasional Paper, No.56, 1988).

Hood, C., "A Public Management for All Seasons", Public Administrations, Vol. 69, Spring, 1991, pp.3-19.

Hoque, A.K.M.Z. and Hopper, T.M., "Rationality, Accounting and Politics: A Case Study of Management Control in a Bangladeshi Jute Mill", Management Accounting Research, Vol.5, No.1, 1994, pp.5-30.

Hoque, A.K.M.Z. and Hopper, T.M., "Political and Industrial Relations Turbulence, Competition and Budgeting in the Nationalised Jute Mills of Bangladesh", Accounting and Business Research, Vol.27, No.2, 1997, pp.125-143.

Humphrey, C.L., Privatisation in Bangladesh - Economic Transition in a Poor Country (Oxford: Westview Press, 1990).

Jensen, M.C. and Meckling, W.H., "Theory of the Firm: Managerial Behaviour, Agency Cost and Ownership Structure", Journal of Financial Economics, Vol.3, August, 1975-May, 1976, pp.305-360.

Jones, C. S. \& Sefiane, C. S., "The Use of Accounting Data in Operational Decision Making in Algeria”, Accounting Auditing and Accountability Journal, Vol.5, No.4, 1992, pp.71-83.

Jones, C.S., "An Empirical Study of the Role of the Management Accounting Systems Following Take-Over or Merger", Accounting, Organizations and Society, Vol.10, No.2, 1985, pp.177-200.

Jones, C.S., "The Attitudes of Owner-Managers towards Accounting Control Systems Following Management Buy-outs", Accounting, Organizations and Society, Vol.17, No.2, 1992, pp.151-168.

Karatas, C., (1995), "Has Privatisation Improved Profitability and Performance of the SOEs in Turkey?" in Cook, P. and Kirkpatrick, C., (eds.), Privatisation Policy and Performance: International Perspectives, pp.244-262 (New York: Harvester Wheatsheaf, 1995).

Killick, T., "The Role of Public Sector in the Industrialisation of African Developing Countries", Industry and Development, (UNIDO), Vol.7, 1983, pp.47-76.

Kim, K., "Enterprise Performance in the Public and Private Sectors: Tanzanian Experience, 1970-75", Journal of Developing Areas, Vol.5, No.3, 1981, pp.471-484.

Larson, R. K. and Kenny, S. Y., "An Empirical Analysis of International Accounting Standards, Equity Markets, and Economic Growth in LDCs", Journal of International Financial Management and Accounting, 6:2. 1995, pp.130-155.

Larson, R. K., "International Accounting Standards and Economic Growth: An Empirical Investigation of Their Relationship in Africa", Research in Third World Accounting, Vol.2, 1993, pp27-43.

Letza, S and Smallman, C., "Est in aqua dulci non invidiosa voluptas - in Purewater There is a Pleasure Begrudged by None: On Ownership, Accountability and Control in a Privatized Utility", Critical Perspectives on Accounting, 12, 2001, pp. 65-85.

Martin, B., “A Plan for Legalised Mugging”, Weekly Mail and Guardian, South Africa, 12 December. 1995. 
Murshed, A.J.M.H., "The Role of Financial Information in Collective Bargaining in a Developing Country: The Case of Bangladesh", Unpublished Ph.D Thesis, 1989, University of Manchester.

Narayanaswamy, R., "Voluntary US GAAP Disclosure in India: The Case of Infosys Technology Limited", Journal of International Financial Management and Accounting, 1996.

Ogden, S. G., "Accounting for Organizational Performance: The Construction of the Customer in the Privatized Water Industry", Accounting, Organisations and Society, Vol. 22, No. 6, 1997, pp. 529$\underline{556 .}$

Ogden, S. G., "Transforming Frameworks of Accountability: The Case of Water Privatization", Accounting, Organisations and Society, Vol. 20, No. 2-3, 1995, pp. 193-218.

Ogden, S., "The Reconstruction of Industrial Relations in the Privatized Water Industry", British Journal of Industrial Relations, Vol. 32, No. 1, March 1994, pp. 67-84.

Ogden, S.G., "The Limitations of Agency Theory: The Case of Accounting-Based Profit Sharing Schemes2, Critical Perspectives on Accounting, Vol. 4, 1993, pp.179-206.

Ogden, S.G., "Accounting for Organisational Performance: The Construction of the Customer in the Privatised Water Industry", Fourth Interdisciplinary Perspectives on Accounting Conference, University of Manchester, July 1994.

Ouibrahim, N and Scapens, R., "Accounting and Financial Control in a Socialist Enterprise: A Case Study from Algeria", Accounting, Auditing \& Accountability Journal, Vol.2 No.2, 1989, pp7-28.

Perera, M.H.B., “Accounting and its Environment in Sri Lanka', Abacus, Vol. 11, 1975, pp.85-96.

Perera. M.H.B., "Accounting in LDCs, A Case for Localised Uniformity", British Accounting Review, Vol.21, 1989, pp.141-158.

Potts, D., "Nationalisation and Denationalisation of State Agriculture in Tanzania 1967-1990", in Cook, P. and Kirkpatrick, C. (eds), Privatisation Policy and Performance: International Perspectives, pp.178-197, (New York: Harvester Wheatsheaf, 1995).

Ramanadhan, V.V., Privatisation in Developing Countries, (London: Routledge, 1989).

Ramaswamy, R.I., “The Privatization Argument”, Economic and Political Weekly, March 12, 1988.

Rees, R., Public Enterprise Economics (London: Weidenfeld and Nicolson, 1984).

Rees, R., "The Theory of Principal and Agents”, Bulletin of Economic Research, Vol.37, No.1, 1985, pp.3-26.

Shaoul, J., "A Critical Financial Analysis of the Performance of Privatised Industries: The Case of the Water Industry in England and Wales", Critical Perspectives on Accounting, 1997, pp. 479-510.

Scott, J.P., Corporation, Class, Capitalism, (London: Hutchinson, 1985).

Sobhan, R. and Ahmad, M., Public Enterprise in an Intermediate Regime: A Study in the Political Economy of Bangladesh, (Dhaka: Bangladesh Institute of Development Studies, 1980).

Sobhan, R., The Decade of Stagnation, The state of the Bangladesh Economy in the Late 1980's, (Dhaka: University Press Limited, 1991). 
Sobhan, R and Ahsan, A., Disinvestment \& Denationalisation: Profile and Performance, (Bangladesh Institute of development Studies: Research Report New Series, no.38, 1984)

Sobhan, R., The Crisis of External Dependence - The Political Economy of Foreign Aid to Bangladesh, (London: Zed, 1982).

Toye, J., Dilemmas of Development, (Oxford: Blackwell, 1994)

Uddin, S.J., Characteristics of Public Enterprise Management in Bangladesh", PhD Thesis, 1987, University of Glasgow.

Uddin, S.N., "The Role of Management Control Systems in Privatisation: A Labour Process Analysis of a Bangladeshi Case Study", Unpublished Ph.D thesis, Manchester School of Accounting and Finance, 1997, University of Manchester.

Uddin, S.N. and Hopper, T.M., "Management Control, Ownership and Development: Illustrations from a Privatised Bangladeshi Enterprise", in M. Mackintosh \& R.Roy (eds), Economic Decentralization and Public Management Reform, pp. 231-271, (London: Elgar, 1999).

Uddin, S.N. and Hopper, T.M., "A Bangladeshi Soap Opera: Privatisation, Accounting, and Regimes of Control in a Less Developed Country", Accounting, Organizations and Society, Oxford; Vol. 26, Nos. 7/8, Oct/Nov 2001, pp. 643-672.

Vickers, J. and Yarrow, G., "Privatisation in Britain", in Paul, W. and MacAvoy, W.T., Privatisation and State Owned Enterprises: Lessons from the United States, Great Britain and Canada, pp.209-246 (London: Kluwer Academic Publishers, 1988).

Wallace, R. S. O. \& Briston, R. J., "Improving the Accounting Infrastructure in LDCs", Research in Third World Accounting, Vol.2, 1993, pp.201-274.

Wallace, R.S.O., "Corporate Financial Reporting in Nigeria", Accounting and Business Research, Vol. 18, No.72, 1988, pp.352-362.

Wickramasinghe, D.P., "Rationales of Accounting Controls and Ownership Change in a Development Context: A Mode of Production Theory Analysis of Two Sri Lankan Case Studies", Unpublished PhD thesis, Manchester School of Accounting and Finance, 1996, University of Manchester.

World Bank, Bangladesh Implementing Structural Reform, (World Bank, Report No-11569-BD, March 24, 1993).

World Bank, Bangladesh: Privatization and Adjustment, (World Bank, 1995).

World Bank, Bangladesh Government That Works Reforming the Public Sector, (Dhaka: University Press Limited, 1996).

World Bank, Annual Economic Update: Recent Economic Developments and Medium-Term Reform Agenda, (World Bank, Country Development I, July, 1996a).

World Bank, Bangladesh an Agenda for Action, (World Bank South Asia Department I, Washington, DC, 1996b).

World Bank, Privatisation Experience in Bangladesh 1991-1996, (Dhaka: World Bank, 1997).

Wortzel, H. and Wortzel, L.H., "Privatization: Not the Only Answer", World Development, Vol.17, No.5, 1989, pp.633-641. 
Wright, M., Thompson S. and Bobbie, K., "Finance and Control in a Privatisation by Management Buy-out", Journal of Management Studies, Vol.30, No.1, 1993, pp.75-99

\footnotetext{
${ }^{1}$ This is a World Bank commissioned report supervised by World Bank (Bangladesh Branch) officials. It was later published in an academic journal by the main researcher, a Consultant Economist of the World Bank (Dowlah, 1998).

${ }^{2} 40$ Taka $=1$ US Dollar in the late 1980s. This rate has gradually declined and at January 2002 it is 1 US Dollar $=56$ Taka.

${ }^{3}$ The government retained $51 \%$ of shares, thereby maintaining control in each company, with the remaining shares being sold privately (Humphrey, 1990).

${ }^{4}$ Empirical research on privatisation in LDCs is sparse and inconclusive (Cook and Kirkpatrick, 1995). Some studies find that SOEs have lower profitability than their private sector counterparts in the same industry (Ayub and Hegstod, 1986; Killick, 1983; Kim, 1981; Funkhouser and MacAvoy, 1979) but others find the converse (Ramaswamy, 1988; Wortzel and Wortzel, 1989). Potts (1995) found improved management after privatisation of enterprises in two states but in others organisational effectiveness declined. Weiss (1995) found no significant evidence that SOEs had inferior performance to private enterprises. The closest development economists have come to studying privatisation and accounting controls is Karatas's (1995) comparative evaluation of pre- and postprivatisation company performance based on financial measures such as turnover, profit margins, and productivity. He found it difficult to demonstrate that privatisation affected performance.
}

${ }^{5}$ Each public sector company should submit annual accounts to the government under the accounting and auditing provisions of the Bangladesh Industrial Enterprises Act.

${ }^{6}$ Shareholders can take the company to court under section 181-209, Company Law, 1994. However, since they are scattered it is difficult for them to take action over the lack of general meeting or published accounts.

${ }^{7}$ According to the wage commission and labour laws of 1993, which would have prevailed had PC still been nationalised, permanent workers would have got a minimum of US\$2 per eight hour shift.

${ }^{8}$ The new democratic government of 1991 abandoned the 51-49 plan of the Ershad military government.

${ }^{9}$ A memorandum of understanding (MOU) was agreed with a Dutch company, Eerste Nederlandse Cement Industries (ENCI), on August 10, 1999 for joint management of CCCG following the transfer of $26 \%$ of CCCG shares to ENCI. SEC officials claimed that despite both parties being aware of securities market regulations calling for immediate dissemination of price sensitive information, news regarding the MOU was not disseminated to stock exchanges or investors until January 16, 2000. The SEC report alleged that in the interim the owner-manager of CCCG engaged his brother to trade CCCG shares in the stock market for illegal gains, whilst keeping investors were kept uninformed of material events. The investigators also claimed that in addition to the MOU, they had possession of a document agreeing to the transfer of the shares that had been concealed from the probe body. Meanwhile, the Dutch company in October 2001 announced its intention to purchase 645,000 shares of CCCG (25\% of total) giving ENCI 51\% ownership of CCCG. The owner-managers of CCCG have also disclosed their intention to sell all their shares in CCCG.

${ }^{10}$ A detail study of the transformation of internal controls in the privatised companies except PC was impossible due to constraints of access and time.

11 This makes economic development synonymous with economic growth and ignores a other development goals. A total view of development includes economic, social, cultural and political factors including access to employment opportunities, personal security, civil rights, minimum needs for physiological well-being (food, shelter, and clothing), and basic services for health, education, and clean water. 